\title{
Foreign Direct Investment of United States of America in Bangladesh
}

\author{
Fahmida Mostafiz ${ }^{1}$ \\ ${ }^{1}$ Lecturer, Department of International Business, Faculty of Business Studies, University of Dhaka, Bangladesh \\ Correspondence: Fahmida Mostafiz, Lecturer, Department of International Business, Faculty of Business Studies, \\ University of Dhaka, Bangladesh. E-mail:fahmidamostafiz@gmail.com
}

Received: March 23, 2017

Accepted: April 21, 2017

Online Published: May 17, 2017

doi:10.5539/ijbm.v12n6p89

URL: https://doi.org/10.5539/ijbm.v12n6p89

\begin{abstract}
The purpose of this paper is to review the Foreign Direct Investment of United States of America in Bangladesh. To pursue the objectives, the study considers the year to year total inflows of FDI and contribution from USA compare to other countries. A time series analysis using simple regression model, Compound growth rate in sectors, investing across borders indicators developed by World Bank group and Market Potential Index conducted by the Michigan state University-International Business Center reveals that, USA average inflow is US\$ 115.89 million which is $13 \%$ out of the total FDI received Bangladesh. Moreover, USA recent investments in Bangladesh are in four sectors: gas and petroleum, power and banking. As, Bangladesh performance relatively better than India, Pakistan and Srilanka in terms of investing across borders indicators, US companies and government of both nations may positively consider the findings of this study when they are going to formulate investment and trade policies. Making a scope of further studies in related field, this paper contribute to the existing knowledge of US investment opportunities in Bangladesh.
\end{abstract}

Keywords: FDI inflow, FDI stock, market potential index, investing across boarders

\section{Introduction}

United States of America (USA) has been a friendly country to Bangladesh from its very beginning and both countries diplomatic relationship marked its 45th anniversary in this year. As the early 1990s, it was largely a relationship based on aid and remittances. In 1990, Americans counted only \$85 million in Bangladeshi imports, largely made up of traditional jute and other primary products, while supplying $\$ 240$ million in relief and development aid. The American investment stakes and export totals were minimal. A generation later, the relationship is defined by trade and investment. The work of Bangladeshi businesses and seamstresses now finds a place in nearly every American home.

In this connection, the American aid commitment to Bangladesh is tiny compared with the $\$ 5$ billion worth of Bangladesh-made goods American buy each year. This very large trade relationship has been the foundation of Bangladesh's growth, which has averaged 6\% per year. According to Islam (2012) in contrast, Bangladesh is a growing market for American products and a significant destination for investment. Bangladesh's businesses, government agencies, and citizens buy about $\$ 500$ million worth of USA products annually, ranging from the cotton and down feathers that serve the Bangladeshi garment industry to airplanes, wheat, soybean oil, and information technology (IT) goods. And the country is the site for more than $\$ 1$ billion in American direct investment, in fields ranging from consumer goods to energy.

From the economic point of view and as a development partner, USA plays a pivotal role. Today, USA is one of the biggest trade partners of the country. The USA is also one of largest development partners, providing $\$ 6$ billion dollars since 1972. USA bilateral trade now stands at 5.4 billion from 4.3 billion in 2010 and 4.8 billion in 2012. In the past three years the two-way bilateral trade grew 11 percent a year on the average with balance of trade in Bangladesh's favor. The USA is one of the largest export markets for Bangladesh consisting of basically five products i.e. knitwear, woven garments, home textiles, shrimp and fish, and headgear which account for 98 per cent.

Most significantly, USA is one of the largest sources of foreign direct investment in Bangladesh. Major USA companies already present and doing business in Bangladesh include 3M, Boeing, Chevron, ConocoPhillips, Citibank, Wells Fargo, and many others. The biggest American investment in the country is the operations of Chevron, which produces 50\% of Bangladesh's gas. Bilateral trade in 2014 stood at US\$6 billion. USA is one of 
the Bangladesh's principal strategic military allies. American defense cooperation is seen as a counterweight to the regional powers India and China. Joint exercises are held on a regular basis, particularly in the Bay of Bengal. The U.S. Pacific Command maintains regular engagements with the Bangladesh Armed Forces.

The USA apparently has an urge to strengthen relations with Bangladesh owing to its geo-strategic importance, growing economy, and moderate Muslim majority country's opposition to extremism. Bangladesh-United States of America relations are based on a strong foundation of bilateral ties and their common stands in most international forums. Both countries are members of the Commonwealth and World Bank, WTO etc. and share their views in the multilateral forums. The two countries therefore, have great potentials in strengthening their economic and social relations, and for this an effort is necessary in bridging the knowledge gaps in both countries about each other, including specially about the market potentials.

\subsection{Objectives}

Given the above general background, there is a need for comprehensive review of the many different aspects of United States -Bangladesh relations, including United States aid to Bangladesh, the trade relations between the two countries, contribution of US to development of human resources in the country and the investment of US in the country. The present paper however, limits its scope in analyzing only the investment relations between United States and Bangladesh and looks into

a. Foreign direct investment of United States of America in Bangladesh including FDI inflows, FDI Stocks and Sector-wise FDI inflows.

b. Potential sectors of Bangladesh for USA investment

c. Potentiality of Bangladesh as an investment destination for USA companies

\section{Methodology}

To determine USA investment in Bangladesh- its total FDI inflows, stocks, sector-wise focuses and prospects, this study adopts a quantitative approach of investigation. According to Creswell (2003), quantitative research adopts statistical procedures to test objective theories by examining the relationship among variables. Therefore, this study considers the application of important but simple statistical procedures which generates intended results from stated objectives. A quantitative research avoids the problem of more time consumption and weaker forms of measurement. According to Bryman (2001), quantitative approach provides more reliability, causality and ability to simplify. Moreover, this study is an exploratory study in nature which is focused on establishing a rationale for US investment in Bangladesh- both in sector-wise and firm wise.

In this connection, the first objective of the study is addressed by a time series analysis of foreign direct investment inflows from USA in Bangladesh for a period between 1996 and 2016. Along with this tread analysis; percentage of the contribution of USA FDI to the total inflows of Bangladesh is also assessed as a reflation of the future prospects. For the time series analysis, the simple straight trend equation used in the study is,

$$
Y=a+b x
$$

Where,

$\mathrm{Y}=$ Trend value of USA FDI inflows (dependent variable)

$\mathrm{x}=$ unit of time (independent variable)

$\mathrm{a}=\mathrm{y}-$ intercept (the approximate fixed FDI inflows at any unit of time)

$\mathrm{b}=$ slope of the line (average increase in FDI inflow in a given unit of time)

Therefore, trend values of the USA net FDI inflows during 1996 to 2016 are assessed by the simple linear regression equation, which states

$$
Y=\alpha+\beta X+\varepsilon
$$

Where, $\mathrm{Y}$ is the USA FDI inflow represented in the equation by $(\widehat{\mathrm{Y}})$, i.e., the average annual value for $\mathrm{Y}$; $\alpha$ is the intercept (representing the smoothened out amount of FDI inflow in the year taken as base year for the estimation; 2006 , in the given case, see table 1B). On the other hand, $\beta$ represents the slope meaning change in the FDI flows because of change in the year by 1; (estimates for parameters $\alpha$ and $\beta$ have been made by using Least Square approach); Moreover, $\mathrm{X}$ is the coded value of a particular year (of FDI inflow; see table 1A); and $\varepsilon$ is the error term meaning the impact of other variables that are not considered in the model.

Thus, the regression equation rewritten for estimates is $\widehat{Y}=\widehat{\alpha}+\widehat{\beta} X$. Where, $\widehat{\beta}=\beta$ value for the sample data or the estimated regression coefficient calculated as, 


$$
\hat{\beta}=\frac{\sum X_{i} Y_{i}-\frac{\sum X_{i} \sum Y_{i}}{n}}{\sum X_{i}^{2}-\frac{\left(\sum \llbracket X_{i}\right)^{2} \rrbracket}{n}}
$$

In this equation, $\widehat{\alpha}=$ estimated intercept and these values are computed as, $\widehat{\alpha}=\bar{Y}-\widehat{\beta} \bar{X}$, where $\bar{Y}=$ average value of USA FDI inflow per year, $\overline{\mathrm{X}}=$ Per year average of the coded values for $\mathrm{X}$ and i stands for years $1,2, \ldots, 21$.

Moreover, FDI stock of USA in Bangladesh has also been assessed in the light of this objective. To assess such a situation, a year-to-year growth rate (YGR) has been calculated. Considering, $\mathrm{X}_{1}=$ previous year value of FDI inflow and $\mathrm{X}_{2}=$ next year value of variable FDI inflow, the equation used in this study for YGR is as follows,

$$
Y G R=\frac{X_{2}-X_{1}}{X_{1}}
$$

However, to assess the second objective that potential sectors of Bangladesh for US investment is measured using the compound annual growth rate (CAGR) calculated for the 5 years period between 2011 and 2015. The equation used in this study for CAGR is as follows,

$$
\text { CAGR }=\left[\frac{X_{n}}{X_{1}}\right]^{t_{n}-t_{1}}-1
$$

Where,

$t_{n}=$ year $n$ and $t_{1}=$ first year (of the period)

$\mathrm{X}_{1}=$ foreign direct investment inflow of a country to a destination in start year (1)

$\mathrm{X}_{\mathrm{n}}=$ foreign direct investment inflow of that country to that destination in end year (n)

Other than use of the compound annual growth rate (CAGR) equation, this study also assess the indicators offered by Investing across Borders, a World Bank Group initiative comparing regulation of foreign direct investment around the world. It presents quantitative indicators on economies' laws, regulations, and practices affecting how foreign companies invest across sectors, start businesses, access industrial land, and arbitrate commercial disputes. In this Paper, IAB has been used to show Bangladesh sectors openness comparing with neighboring countries like India, Sri Lanka and Pakistan for foreign investment as well as starting business, assessing land and arbitration facilities for doing business in those sectors. Based on data of 2015, investment across borders indicators is assessed.

Finally, the third objective, named potentiality of Bangladesh as an investment destination for US firms' is evaluated by Market Potential Index (MPI). The MPI is a systematic and formal analysis which was originally developed by the Michigan State University-International Business Center (1996) to identify aggregate market potential and ranking 87 countries based on eight dimensions. Market Potential Index provides a good starting point for U.S. companies to evaluate the overall market potentiality in determining particular nations for expansion. In this paper MPI has been used to show Bangladesh investment potentiality comparing with that of neighboring countries such as India, Pakistan and Sri Lanka.

To assess the competitiveness, comparison among countries has been made based on MPI database, published by Global Edge in 2016. Eight dimensions such as market size; market intensity; market growth rate; market consumption capacity; commercial infrastructure; market receptivity; economic freedom and country risk, are chosen to represent the market potential of a country on a scale of 1 to 100. The dimensions are measured using various indicators, and are weighted in determining their contribution to the overall Market Potential Index (MPI).

Other than the model specification and data analysis techniques, this study focuses on established data from relevant sources to analyze, compare and make relation among variables rather than generating raw data though primary data collection methods. Therefore, it is based on secondary sources, more specifically the Board of Investment (BOI) of Bangladesh and Bangladesh Bank (for data on foreign direct investment of Bangladesh) and ITC Trade Map (for globally accepted trade data, including for United States), UNCTAD, World Bank, and World Economic Forum. Though, the time period is considered from 1996 to 2016 for all the assessment, due to non-availability of uniform sets of data, not all parameters and indices could be assessed and analyzed by using data for same time periods. Moreover, this study adopts MS excel latest version for descriptive analysis of the variables and for the statistical analyses, Statistical Package for the Social Science (SPSS) version 21.0 is used. 


\section{Discussion and Findings}

\subsection{Foreign Direct Investment from USA in Bangladesh}

\subsubsection{FDI Inflow from United States in Bangladesh}

United States is one of the largest sources of foreign direct investment in Bangladesh. At least for the last two decades, the pattern of US FDI inflows reveals a major contribution of it to the total. Table 1A shows this comparative picture for the time period of 1996 to 2006. Within this period, the average contribution of US investment inflows is around $13 \%$ of the total inflows in Bangladesh. However, in a single year, major contribution $40 \%$ came in 1998 followed by $34 \%$ (in 2015) and 22\% (in 1999, 2006, and 2016). Lowest contribution reported is only $3 \%$ in 2014 also. In addition to these, the largest American investment in the country is the operations of Chevron, which produces around $50 \%$ of Bangladesh's natural gas.

Table 1a. USA FDI inflows in Bangladesh from 1996 to 2016

\begin{tabular}{llll}
\hline Year & $\begin{array}{l}\text { Total FDI inflows } \\
\text { (In Million US\$) }\end{array}$ & $\begin{array}{l}\text { USA FDI inflows } \\
\text { (In Million US\$) }\end{array}$ & \% of Total FDI \\
\hline 1996 & 231.6 & 14.39 & $6 \%$ \\
1997 & 575.5 & 67.64 & $12 \%$ \\
1998 & 576.5 & 232.9 & $40 \%$ \\
1999 & 309.1 & 66.9 & $22 \%$ \\
2000 & 578.6 & 29.34 & $5 \%$ \\
2001 & 354.5 & 30.85 & $9 \%$ \\
2002 & 335.5 & 24.5 & $7 \%$ \\
2003 & 350.3 & 32.1 & $9 \%$ \\
2004 & 460.4 & 61.76 & $13 \%$ \\
2005 & 845.3 & 141.8 & $17 \%$ \\
2006 & 792.5 & 175.72 & $22 \%$ \\
2007 & 666.4 & 120.36 & $18 \%$ \\
2008 & 1086.3 & 40.92 & $4 \%$ \\
2009 & 700.2 & 42.89 & $6 \%$ \\
2010 & 913.3 & 56.95 & $6 \%$ \\
2011 & 1136.4 & 117.74 & $10 \%$ \\
2012 & 1292.6 & 43.8 & $3 \%$ \\
2013 & 1599.1 & 75.95 & $5 \%$ \\
2014 & 1526.7 & 33.67 & $2 \%$ \\
2015 & 1700 & 573.77 & $34 \%$ \\
2016 & 2003.53 & 449.74 & $22 \%$ \\
\hline
\end{tabular}

Source: Bangladesh Bank, Survey report, 2016.

Evaluating the time series of US investment inflows in Bangladesh, trend values of the USA net FDI inflows during 1996 - 2016 are assessed by the simple linear regression equation. The figures (Table 1B in appendix) relating to US inflow of FDI in Bangladesh in different years during the period 1996 - 2016, when fit in the regression line developed as above, show that the value of the error term $(\varepsilon)$ works out as zero making the regression equation as $\widehat{Y}=115.89+10.39 \mathrm{X}$ in which the adjusted coefficient of determination $\mathrm{R}^{2}=0.80$ (or $80 \%$ ) with a significance level of 0.001 .

Thus, the model estimated altogether implies the following issues; first the model is well-fitted to the data, since it is well fitted to $80 \%$ of the sample data. Second, when all the years are kept at a fixed level, the average annual FDI inflow is US $\$ 115.89$ (since $\widehat{\alpha}=115.89$ ). Third, for a change in time by 1 year, the FDI inflow changes by US $\$ 10.39$ (since $\widehat{\beta}=10.39$. and fourth, the regression parameters are highly significant (since, $p$ value $=0.001$ ) at $1 \%$ level of significance, which indicates that the time- FDI flow relations are satisfactorily explained by an accuracy of $99 \%$. This model representation and relationship explained graphically in the following (figure 1). 


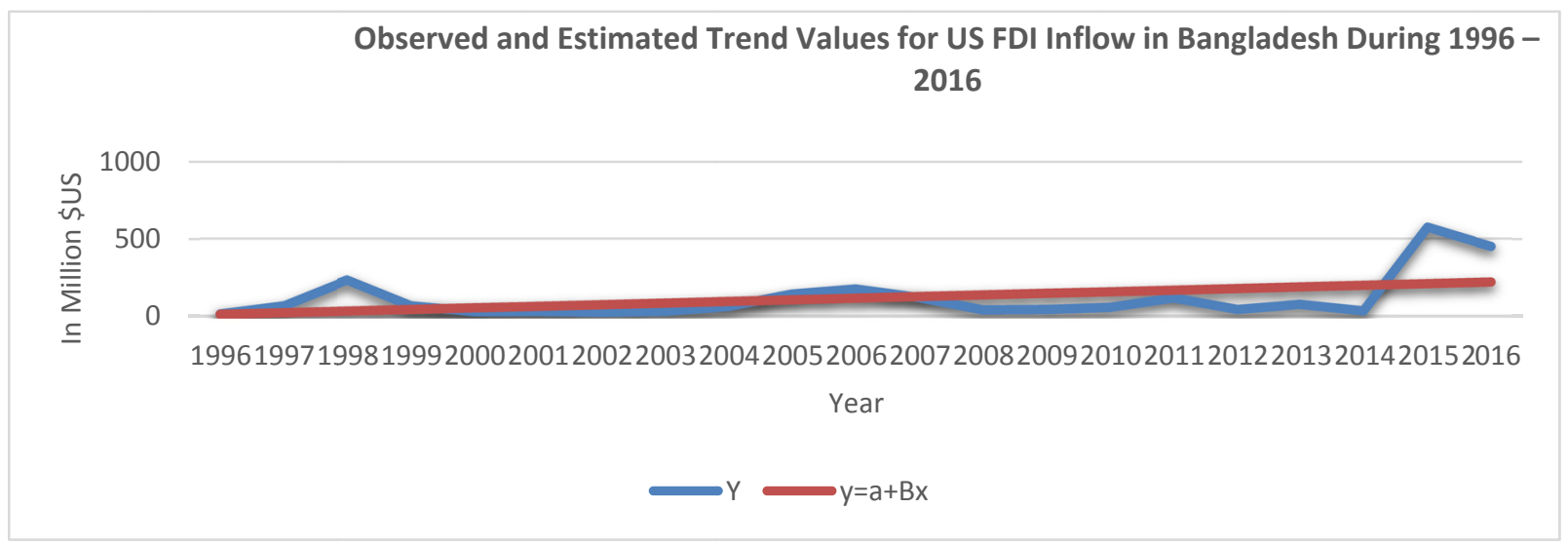

Figure 1. Observed and Estimated Trend Values for USA FDI Inflow in Bangladesh during 1996-2016

Source: Author's calculation.

\subsubsection{FDI stock from United States of America in Bangladesh}

The stock of USA FDI in Bangladesh (measured by the level of economic value of FDI i.e., the sum of the net worth, considering assets and liabilities, of all establishments having FDI) increasing slowly until the year 2005. It rose from US \$687.45 million in the year 2006 to US \$3204.85 million to in 2016, making United States the number one leading country in terms of stock of FDI in Bangladesh. Other leading countries in descending order in this count were United Kingdom (US\$ 1526.37 million), South Korea (US\$ 1082.43 million), Australia (US\$ 914.25 million), Netherlands (US\$ 743.19 million), Malaysia (US\$ 691.97 million), Hong Kong (US\$ 690.99 million), Malta (US\$ 474.21 million), Singapore (US\$ 425.28 million) and Taiwan (US\$ 330.04 million) which were $23.83 \%, 11.35 \%, 8.05 \%, 6.80 \%, 5.53 \%, 5.15 \%, 5.14 \%, 3.53 \%, 3.16 \%$ and $2.45 \%$ respectively towards the contribution of total FDI stock in 2016.

Moreover, in comparison to the other major investor countries of Bangladesh from the year 2000 to 2016, it is revealed that the US FDI stock is higher than that of Japan and South Korea but lower than that of UK. But from the year 2015 to 2016, US crossed UK with a huge gap such as US\$2811.94 and US\$ 3204.85 to US\$ 1294.42 and US\$ 1526.37 and become number one investor country of Bangladesh in terms of FDI stock. According to Bangladesh bank survey report-2016, the year to year level of US FDI stock in Bangladesh for the period of 2000 to 2016 is represented in following figure 2. This graph shows a gradual improvement of FDI stock in Bangladesh accept the last two years where slope of the growth is very sharp. As mentioned earlier, in 2015 and in 2016 the stock of FDI is considered as US\$2811.94million and US\$ 3204.85 million respectively.

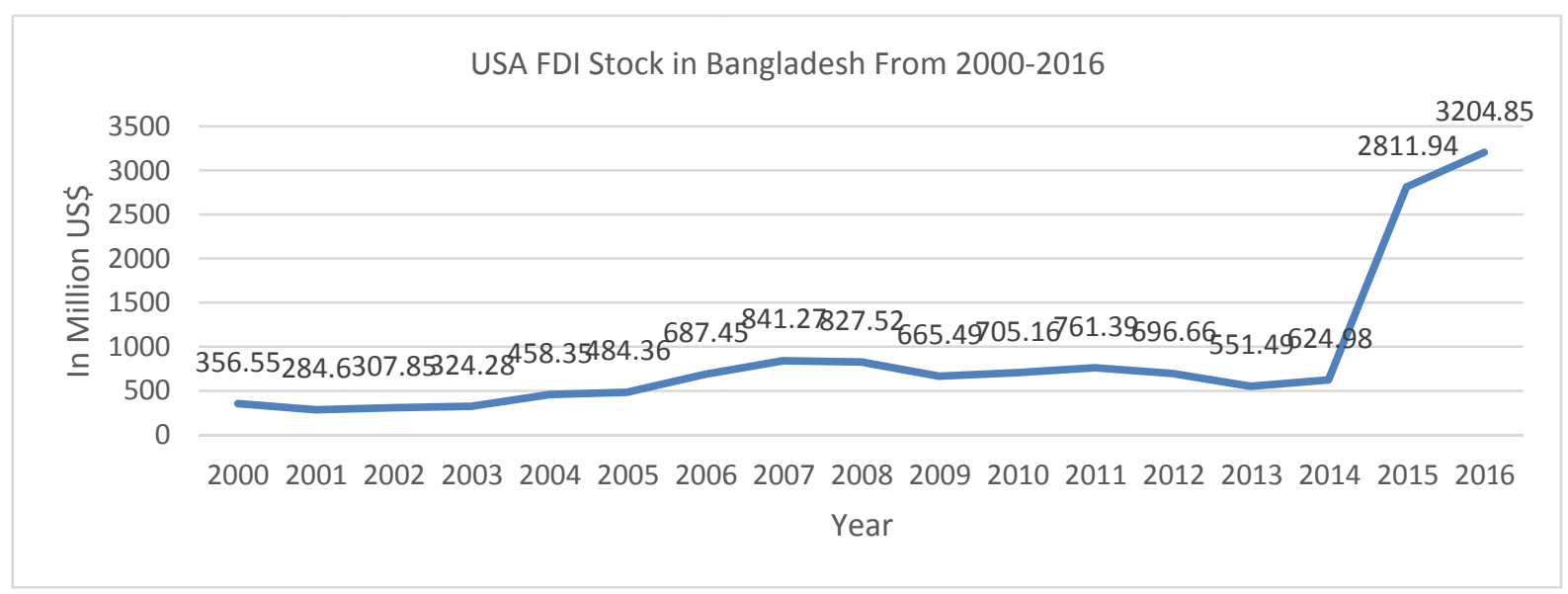

Figure 2. USA FDI Stock in Bangladesh from 2000-2016

Source: Bangladesh Bank, Survey Report, 2016.

Moreover, the year to year growth rate of US FDI stock in percentage from year 2000 to 2016 is also presented 
in following table (Table 2). Therefore, the growth of US stock has a positive growth in all years of the selected period except the following years, 2001, 2008 to 2009 and also 2012 and 2013. Additionally, in 2015 annual growth rate is unexpectedly very high and then the following year it slowed down to a normal position. Moreover, a comparative picture of USA FDI Stock with other major investor countries of Bangladesh is also presented in following figure 3 .

Table 2. Year to year Growth Rate of USA FDI Stocks in Bangladesh

\begin{tabular}{lll}
\hline & & \\
year & USA FDI Stock (in million US\$) & Year to year Growth rate \\
\hline 2000 & 356.55 & - \\
2001 & 284.6 & $-20 \%$ \\
2002 & 307.85 & $8 \%$ \\
2003 & 324.28 & $5 \%$ \\
2004 & 458.35 & $41 \%$ \\
2005 & 484.36 & $6 \%$ \\
2006 & 687.45 & $42 \%$ \\
2007 & 841.27 & $22 \%$ \\
2008 & 827.52 & $-2 \%$ \\
2009 & 665.49 & $-20 \%$ \\
2010 & 705.16 & $6 \%$ \\
2011 & 761.39 & $8 \%$ \\
2012 & 696.66 & $-9 \%$ \\
2013 & 551.49 & $-21 \%$ \\
2014 & 624.98 & $13 \%$ \\
2015 & 2811.94 & $350 \%$ \\
2016 & 3204.85 & $14 \%$ \\
\hline
\end{tabular}

Source: Author's Own Calculation.

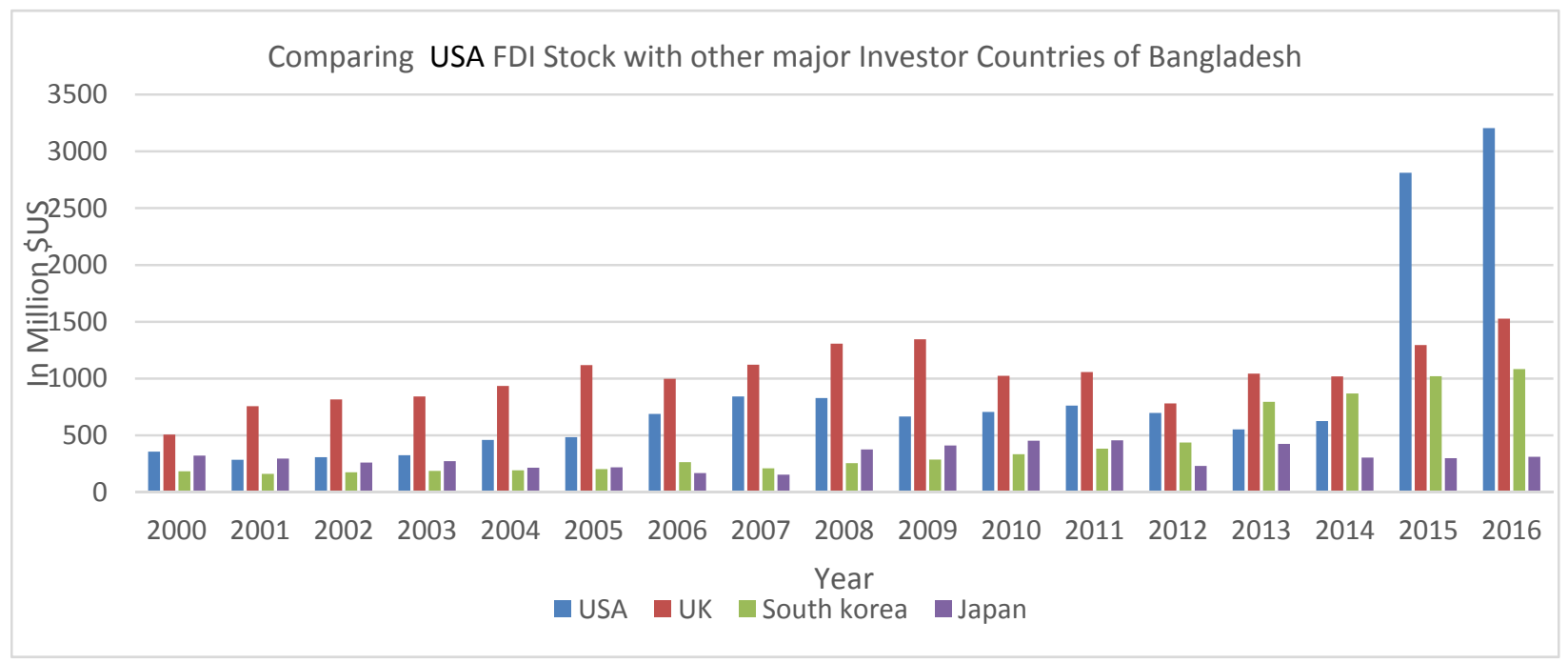

Figure 3. Comparing USA FDI Stock with other major Investor Countries of Bangladesh

Source: Bangladesh Bank, Survey Report, 2016.

\subsubsection{Sector-wise FDI Inflow from United States of America in Bangladesh}

A closer look on stock of USA investment in Bangladesh discloses the preferred sectors for FDI. The data for USA FDI in the period 2014-2016 reveals that the preferred sectors for FDI in the country are telecommunications, textiles, energy (gas, petroleum and power) and banking. However, sectors like agriculture, IT, leather and chemicals also got some FDI in the period. A comparative picture of important sectors for recent 
FDI stocks of USA in Bangladesh for the period of 2014-2016 is presented on following figure 4.

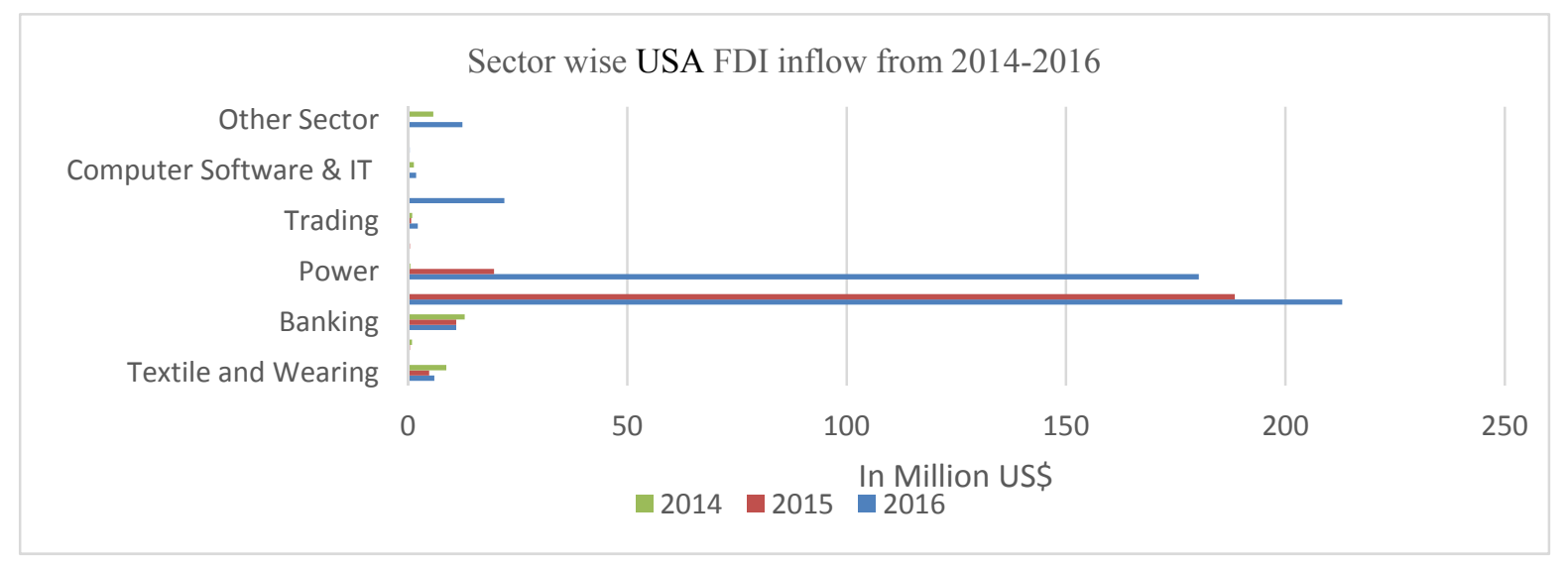

Figure 4. Sector wise USA FDI inflow from 2014-2016

Source: Bangladesh Bank, Survey Report, 2016.

In this regard, it is evident that, U.S. investments in Bangladesh have focused mainly on the energy and power sectors (79\%), the financial sector (insurance, banks, and varied services), along with some in manufacturing. By far, the largest and most important U.S. investor in Bangladesh is Chevron, which has operated three gas fields-Bibiyana, Molvibazar, and Jalalabad - in the Sylhet region for a number of years. Chevron's development of gas fields has increased steadily, and the company now supplies approximately $50 \%$ of Bangladesh gas explained by Ahmed, (2016). Another US company Conoco-Philips is also in the process of being engaged in gas exploration in the Bay of Bengal. But bureaucratic inefficiency, lack of effective decision-making and overall political uncertainty inhibit desirable level of U.S. investment in Bangladesh.

\subsection{Potential Sectors of Bangladesh for USA Investment}

\subsubsection{Potential Sectors of Bangladesh}

Today, $60 \%$ of Bangladesh economy is connected with the global economy. It is also a good market for USA products as the number of middle class people with disposable incomes is rising. Bangladesh could be an integral part of the New Silk Road envisioned by the US that will connect Central Asia, Afghanistan, Pakistan, India, Nepal, Bhutan, Myanmar and China. Moreover, major advantages of Bangladesh as potential destination for FDI is the country's strategic geographic location potentially attractive connectivity with neighboring and even many distant countries by road and sea, availability of cheap labor (around $80 \%$ of Bangladesh is under age 40 year old, 65 percent under age 25) a large domestic market with a vast population having increased consumer buying power, and a growing middle class and of the consumer industry providing a base for fast development of an entrepreneurship class to act as support agents for FDI in the country.

According to International Affairs department of US Chamber of Commerce report in 2013, the leading commercial sectors for US investment include, power systems; computers/peripherals and computer software; textile machinery/equipment; architectural, construction and engineering services; oil, gas and mineral exploration/production services; and pharmaceutical machinery/ equipment. Also according to Bernicat (2016) Bangladesh highlighted investment opportunities in power, pharmaceuticals, information technology, telecom and infrastructure. The calculation of the Compound Growth Rate (CGR) of different potential sectors for FDI inflows in Bangladesh from USA also supports that, all the sectors which US Chamber of Commerce identified in their report, have received high volume of FDI for the period of year 2011 to 2015 . The pattern of CGR in percentage for these potential sectors of US FDI is presented in the following table 3. 
Table 3. Sectors FDI inflows compound growth rate from 2011-2015

\begin{tabular}{ll} 
Sector & CGR (\%) \\
\hline Power & 44 \\
Gas \& Petroleum & 16 \\
Computer Software \& IT & 28 \\
Textiles \& Wearing & 13 \\
Chemicals \& Pharmaceuticals & 23 \\
Construction & 82 \\
\hline
\end{tabular}

Source: Bangladesh Bank, Survey Report, 2015.

Power Sector: Bangladesh is a proven case of secured investment in power sector offering a win-win situation for all parties involved. The incentive package for FDI and for power sector in particular is one of the most competitive. After calculating compound annual growth rate of FDI inflows from the year 2011 to 2015, power sector rate is $44 \%$. This indicates a strong investment potentiality of the sector toward the United States companies.

Oil, Natural Gas and Petroleum: Bangladesh has encouraged foreign oil companies to do business in the country because local firms are not enough to fulfill the huge demand. Bangladesh's natural gas demand is expected by some independent analysts to grow by around 6\% annually over the next two decades. The US Geological Survey recently estimated that Bangladesh contains an additional $32.1 \mathrm{Tcf}$ in additional "undiscovered reserves." Bangladesh may have the potential to become a major gas producer (as well as supplier to the vast potential market in neighboring India) at some point. After calculating compound annual growth rate of FDI inflows from the year 2011 to 2015, Gas and Petroleum sector rate is $16 \%$. This indicate a strong investment potentiality of the sector toward the United States companies.

Textiles: The Bangladeshi textile-clothing industry has grown into a $100 \%$ export-oriented industry. The government facilitates this industry through the duty-free importing of raw materials, cash incentives, duty drawbacks, back-to-back credit, and bonded warehouses, etc. A total $100 \%$ of export-oriented firms do not sell their finished products in the local market. The importing of finished clothing is used to satisfy local demand. Compound growth rate for this sector is $13 \%$ calculated.

ICT and Computer Industry: Bangladesh's ICT industry has been developing slowly over the past three decades, culminating to hundreds of millions of dollars of value addition every year recently. In fact, Bangladesh is now considered to be among the next high prospect destinations in the segment, with accolades from AT Kearney, Gartner, Goldman Sachs and a host of others. Compound growth rate for this sector is $28 \%$ which also indicate the most potential sector of US firms.

Pharmaceuticals: The Pharmaceutical sector is one of the most developed among the manufacturing industries in Bangladesh, although it is still small compared to other comparable sectors. The increase in awareness about healthcare, higher income and increasing government expenditure have resulted in higher demand for medicine. The Drug Policy of 1982 has helped the industry grow by 65 times from BDT 1730 million to BDT 113 billion now, according to IMS report (2014). Compound growth rate for this sector is $23 \%$ which also indicate the most potential sector of US firms.

Construction Industry: The building construction industry is considered as one of the fastest growing and largest sectors in Bangladesh. According to Bangladesh Bureau of Statistics, the construction sector accounted for a record 9.1\% of GDP (Gross Domestic Product) in fiscal year 2012/13. Compound growth rate for this sector is $82 \%$ which also indicate the most potential sector of US firms.

\subsubsection{Comparison of Investing Across Borders Indicators among Bangladesh, India, Pakistan and Sri Lanka}

Bangladesh is one of the most open countries to foreign equity ownership, as measured by the Investing across Sectors indicators specially comparing India, Pakistan and Sri Lanka. All of the 33 sectors covered by the indicators are fully open to foreign capital participation in Bangladesh. In practice certain strategic sectors, including port and airport operation, railway freight transportation, and electricity transmission and distribution are dominated by publicly owned enterprises operating under monopolistic market structures, representing obstacles for foreign investors. Furthermore, registration of a foreign investment project with the Bangladesh Investment Development Authority BIDA (BIDA) is currently only possible for investors in the manufacturing sectors. Investments in the service sectors do not enjoy the benefits associated with this registration (for example 
free repatriation of profits).

Starting of business indicators showed that two shareholders are required to form a limited liability company (or private limited company) in Dhaka. It takes approximately 55 days to set up a foreign-owned subsidiary engaging in international trade in Bangladesh, longer than the Pakistan and India but shorter than Sri Lanka. Only 1 procedure is specific to foreign-owned businesses - the authentication of the parent company's documentation abroad which is one of the major advantages Bangladesh provide to foreign investor companies rather than Pakistan, India and Sri Lanka. This authentication is required to file as a shareholder with the Registrar of Joint Stock Companies and Firms (RJSC) prior to incorporation.

However, investment approval is not a mandatory prerequisite, although it is helpful to register with BIDA in order to have access to the different facilities and institutional support provided by the government to registered investors. Permission to open a foreign-exchange bank account may be granted by Bangladesh Bank (Central Bank) on a case-by-case basis subject to adequate justification and compliance with the Bank's foreign-exchange transaction guidelines. There is no minimum paid-in capital requirement for setting up a foreign LLC in Bangladesh comparing to India. However, the BIDA will not issue a work permit for companies investing less than $\$ 50,000$.

Moreover, foreign-owned companies seeking to access land in Bangladesh have the option to lease from both private and public owners. It is not possible, however, for a foreign company to buy publicly held land, unlike private land like other countries. A foreign-owned company may not buy agricultural land. Leases of publicly owned land may be granted for up to 99 years in Bangladesh than India and Sri Lanka. Leases for privately owned land can be of unlimited duration. Lease contracts can offer the lessee the right to subdivide, sublease, or mortgage the leased land, or use it as collateral. There are no restrictions on the amount of land that may be leased. Currently there is no land information system (LIS) or geographic information system (GIS) in Bangladesh. One of the major disadvantages of Bangladesh comparing with these three countries is that most land-related information may not be found in the land registry.

Furthermore, the Arbitration Act (2001) governs both domestic and international arbitrations in Bangladesh, although there is no statutory definition of domestic arbitration. The statute is based on the UNCITRAL Model Law, although there are a few differences. The Arbitration Act, for example, grants the high court division of the Supreme Court of Bangladesh, the power to determine the jurisdiction of the arbitral tribunal in certain circumstances. Commercial matters can generally be submitted to arbitration. Arbitration agreements must be in writing. The parties are free to select arbitrators of any gender, nationality, or professional qualifications in both domestic and international arbitrations.

However, foreign counsel cannot represent parties in arbitral proceedings unless they are locally licensed. There is no institution in Bangladesh same as Sri Lanka and Pakistan comparing with India which has separate specifically administers arbitrations. Although the arbitration law is modern, in practice, the courts in Bangladesh are not yet fully supportive of the arbitration process. Additionally, the domestic courts are overburdened, which lengthens the enforcement process. On average, it takes around 26 weeks to enforce an arbitration award in local courts which is very short time taken comparing with India, Pakistan and Sri Lanka. These facts are comparatively presented in following table 4 .

Table 4. Comparison of investing across borders indicators among Bangladesh, India, Pakistan and Sri Lanka

\begin{tabular}{|c|c|c|c|c|}
\hline & Bangladesh & Pakistan & Sri Lanka & India \\
\hline \multicolumn{5}{|l|}{ Investing Across Sectors (0-100) } \\
\hline Agriculture \& Forestry & $100 \%$ & $100 \%$ & 100 & 50 \\
\hline Light Manufacturing & $100 \%$ & 100 & 100 & 81.5 \\
\hline Transportation & $100 \%$ & 79.6 & 100 & 60 \\
\hline Mining, Oil and Gas & $100 \%$ & 100 & 40 & \\
\hline Telecommunication & $100 \%$ & 100 & 100 & 74 \\
\hline Electricity & $100 \%$ & 100 & 71.4 & \\
\hline Banking & $100 \%$ & 49 & 100 & 87 \\
\hline Insurance & $100 \%$ & 51 & 100 & 26 \\
\hline Media & $100 \%$ & 37 & 40 & 63 \\
\hline construction, tourism \& retail & $100 \%$ & 100 & 100 & 84 \\
\hline Health care \& waste mgt & $100 \%$ & 100 & 100 & 100 \\
\hline
\end{tabular}




\begin{tabular}{|c|c|c|c|c|}
\hline \multicolumn{5}{|l|}{ Starting a Foreign Business } \\
\hline Time (days) & 55 & 11 & 6 & 16 \\
\hline Procedures (number) & 9 & 27 & 65 & 46 \\
\hline Ease of Establishment (0-100 max) & 55.3 & 64.7 & 47.9 & 76 \\
\hline \multicolumn{5}{|l|}{ Accessing Industrial Land } \\
\hline Strength of lease rights index $(\mathbf{0}=\min , \mathbf{1 0 0}=\max )$ & 100 & 85.7 & 85 & 93 \\
\hline Strength of ownership rights index $(0-100)$ & 100 & 100 & 87 & 88 \\
\hline Access to land information index $(0-100)$ & 26.3 & 10.5 & 31.6 & 16 \\
\hline Time to lease private land(days) & 58 & 59 & 68 & 90 \\
\hline Time to lease public land(days) & 240 & 96 & 91 & 295 \\
\hline \multicolumn{5}{|l|}{ Arbitrating Commercial Disputes } \\
\hline Strength of laws index $(0-100)$ & 85 & 95 & 95 & 89 \\
\hline Ease of Process Index $(0-100)$ & 68 & 69 & 71 & 88 \\
\hline Extent of Judicial assistance index $(0-100)$ & 55.3 & 36 & 38 & 53 \\
\hline
\end{tabular}

Source: The World Bank Group, Investing Across Borders, 2016.

\subsection{Potentiality of Bangladesh as an Investment Destination for USA Companies}

The potentiality of Bangladesh as an investment destination for US firms can be measured through Market Potential Index (MPI). As previously discussed in methodology of this paper, MPI is a way to evaluate and compare important destination for FDI for US firms. Therefore, this study contemplates the MPI of Bangladesh by comparing with some neighboring countries such as India, Pakistan and Sri Lanka. According to MPI 2016, Bangladesh in the overall country rank stands at 54 out of 87 countries with score 21, which is better than Sri Lanka (19) and Pakistan (18) but lower than India (49). The overall score and key indicators of Bangladesh in MPI of 2016 are presented in the following figure 5,

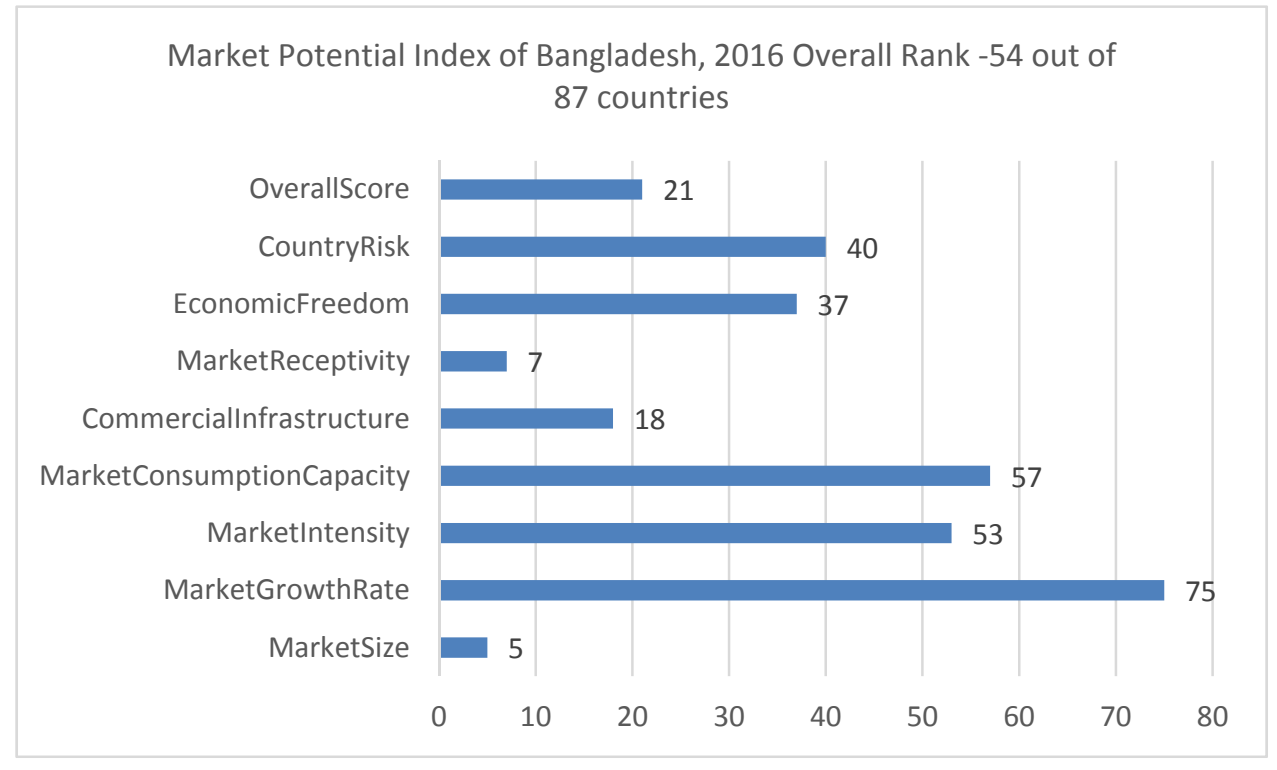

Figure 5. Market potential index of Bangladesh in 2016

Source: Market Potential Index, 2016.

The first of eight indicators used in the Market Potential Index is the market size. Business website global EDGE weights this as the most important of the indicators. Urban population numbers and the amount of electricity consumed provides the basis for the market size indicator. Bangladesh market size is better than Sri Lanka, Pakistan but lower than India. Besides, growth rate of the markets shows increasing demand for products. From the following figures, it has been identified that Bangladesh market growth close to India and Sri Lanka but higher than Pakistan. 


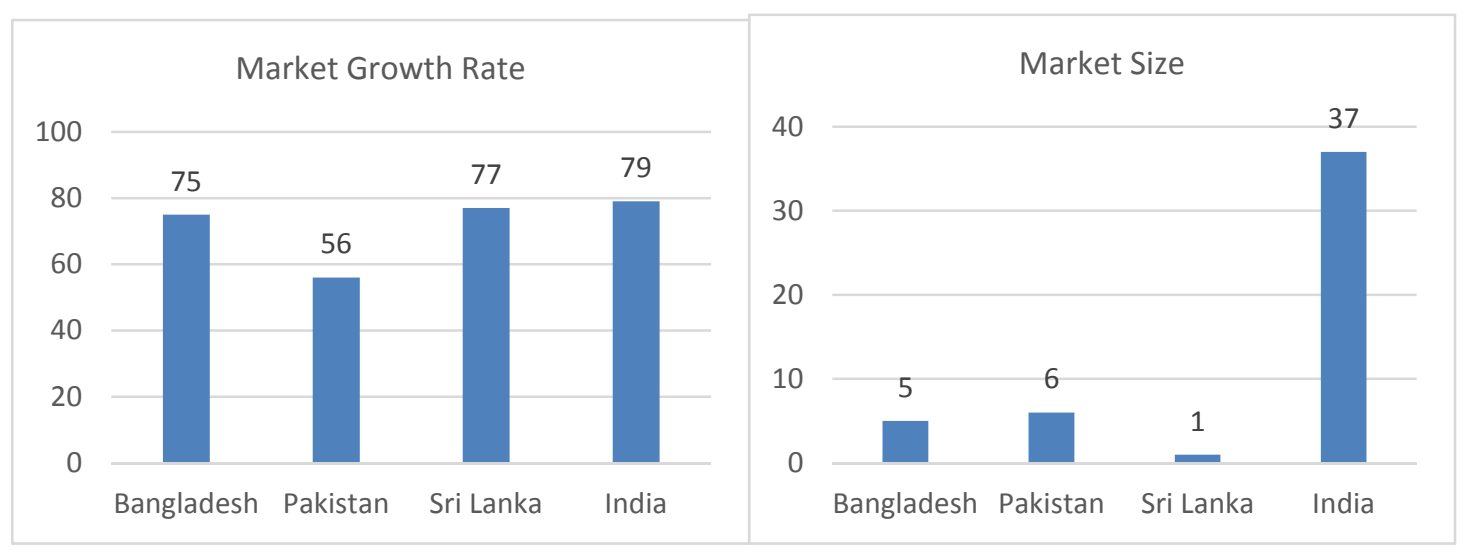

Source: Market Potential Index, 2016.

On the other hand, market intensity is figured by blending two statistics. First, an analyst must divide the gross national income by the population figures. Second, the statistician needs to calculate how much of the gross domestic product is being consumed in the private sector. Moreover, analysis of the national income and consumption is necessary to ascertain the market consumption capacity. Determining the market share of the middle-class factors into the overall Market Potential Index. From the following figures it has been identified that Bangladesh market consumption capacity close to India and Pakistan but higher than Sri Lanka. Figure 7 also represents comparison of market intensity.
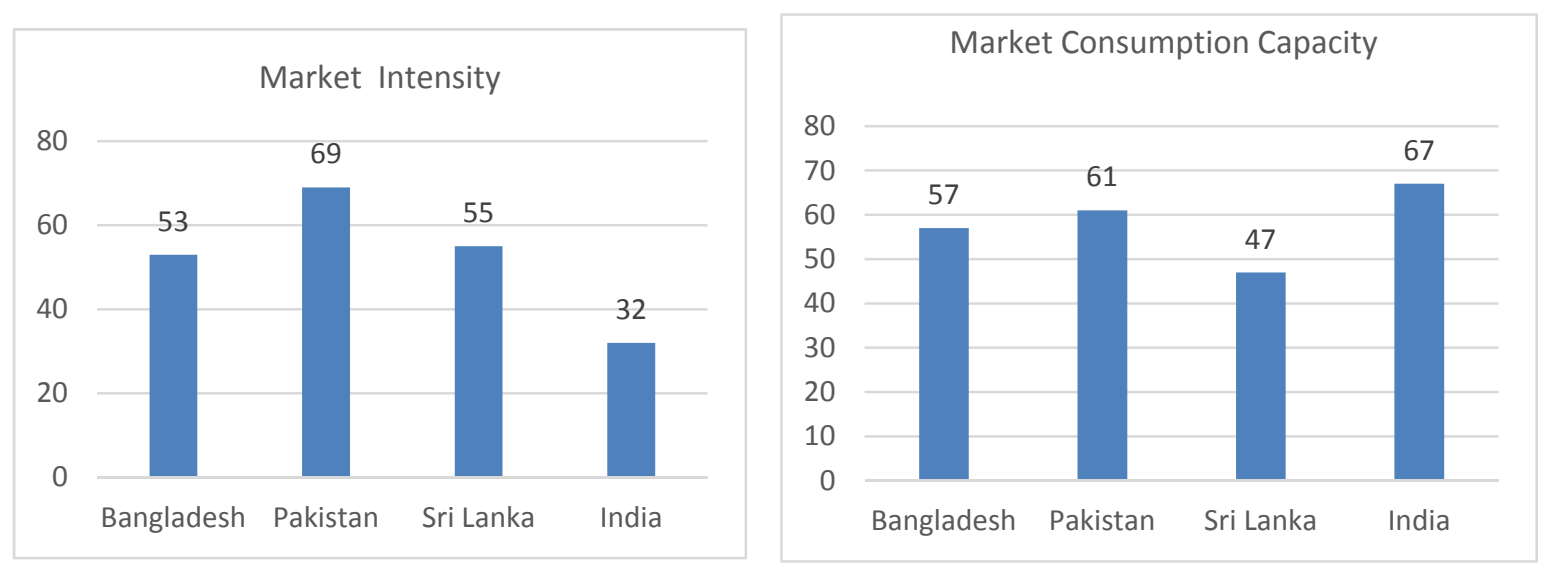

Source: Market Potential Index, 2016.

However, economic freedom relates to the degree of citizens' autonomy. Included in this weighted ratio is the degree of political freedom the residents enjoy. Bangladesh economic freedom position better than Sri Lanka and Pakistan. Some high-consuming countries rely heavily on imports, while others are able to produce the majority of products within the national borders. Reviewing the amount of imports in relation to the gross domestic product might reveal how willing the country is to try new foreign products. In case of country risk Bangladesh position better than Pakistan and same as Sri Lanka but lower than India. The comparison is shown in the following figures. 


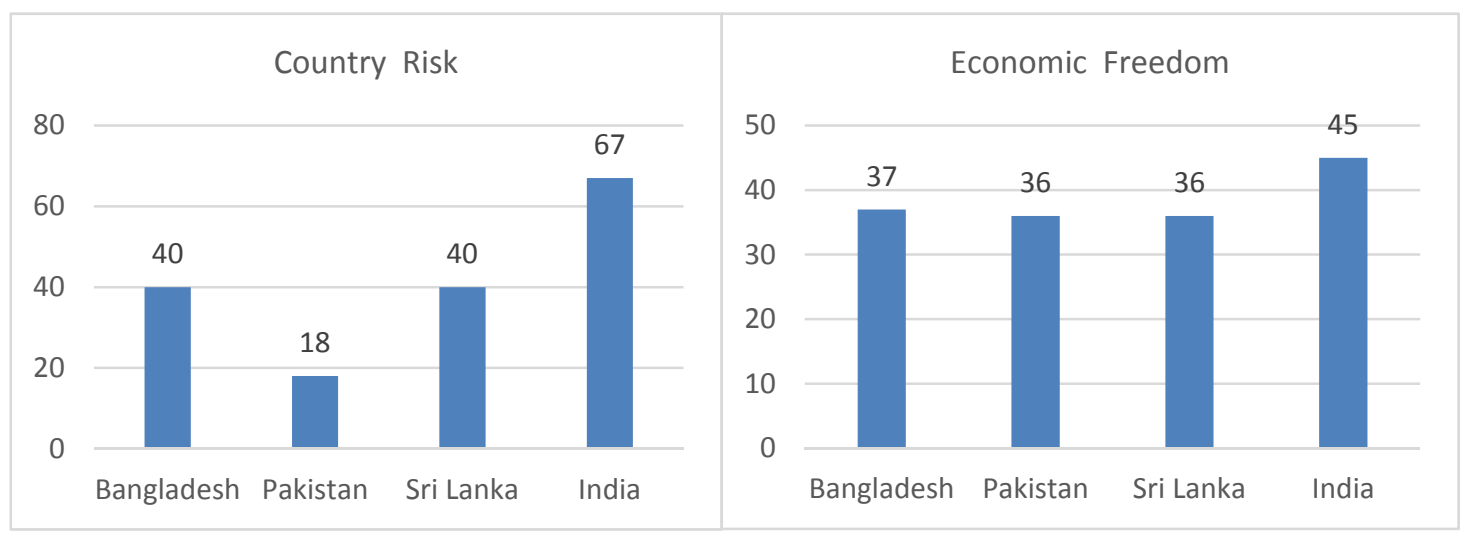

Source: Market Potential Index, 2016.

Thus, in comparison with these three major countries eligible for US companies' investment, Bangladesh in most of the cases better than Sri Lanka and Pakistan except commercial infrastructure and market receptivity. Such a comparison would be helpful to justify and selection of Bangladesh as destination of FDI rather than other neighboring competing countries.

\section{Conclusion}

This study examines the investment relationship between USA and Bangladesh rather than trade and development aid and support. This study reveals that, USA is the major source of FDI inflows in Bangladesh, especially for the last two decades. On this period, the average contribution of US investment on total inflows of FDI accounts around $13 \%$. Moreover, when evaluated on a single year basis, largest percentage of contribution reported for the year of 1998 (40\%) followed by 2015 (34\%) and lowest for the year of 2014 (3\%). Additionally, the largest amount of FDI came in the year 2015 (US\$ 573.77 million) after a slow gradual improvement in previous couple of years. These findings also state that, though United Kingdom is considered the major source of FDI inflows in Bangladesh, as a percentage contribution of total FDI, USA is also a significant nation.

Moreover this paper also considers a time series analysis on US FDI inflows in Bangladesh to predict the future trend on this category. Based on the simple regression analysis for the period of 1996 to 2016, model is well fitted to $80 \%$ sample data. According to the model, when all the years are kept at a fixed level, the average annual FDI inflow is US $\$ 115.89$ and a change in time by 1 year, the FDI inflow changes by US $\$ 10.39$ with $1 \%$ level of significance. This trend analysis also supports that, if all other factors remain constant, Bangladesh can expect a static growth and contribution from US investment.

In addition to these analyses to inflows of FDI from USA, this study also considers the balance and growth of FDI stock from USA. This analysis again extended by a comparative study of FDI stocks of USA in Bangladesh with that of other countries. The findings reveal that, from the perspective of current FDI stock, USA is number one investor of Bangladesh. Though UK has the potential advantageous position over USA in terms of FDI inflows, USA holds the first position when consideration comes for FDI stocks. When in 2006, FDI stock was US $\$ 687.45$ million it is now US $\$ 3204.85$ million in 2016. Moreover, in comparison to the other major investor countries of Bangladesh from the year 2000 to 2016, it is revealed that the US FDI stock is higher than that of Japan and South Korea but lower than that of UK. Significantly, in 2015, annual growth rate is unexpectedly very high accounted for $350 \%$.

A narrower focus is also given in this paper to identify the potential sectors of Bangladesh for US investment. The data for US FDI in the period 2014 - 2016 reveals that the sector-wise historically major inflows came to the telecommunications, textiles, energy (gas, petroleum and power) and banking sectors, especially energy and power sectors (79\%). Moreover, Cumulative Growth Rate calculation in the study also reveals that, Bangladesh has potentials of growth in sectors like energy, construction, pharmaceuticals, textile and ICT in which more US FDI can be facilitated in future.

This study not only reveals US potentiality in Bangladesh for FDI through calculating recent inflows, stocks and sector-wise data, but also accumulates established market indicators provided for US investors. Among those, significant one is investing across borders indicators developed by World Bank group. According to that report and analyzed in this study reveals that, Bangladesh can be a potential destination for USA companies since it has a large market size, high market growth rate and consumption capacity, moderate economic freedom and country 
comparing with Srilanka and Pakistan. Moreover, according to Market Potential Index conducted by the Michigan states University-International Business Center reveals that Bangladesh performance relatively better than India, Pakistan and Srilanka in terms of investing across borders indicators.

Thus, this study contributes to the existing knowledge of USA investment opportunity in Bangladesh. As mentioned earlier that USA is always considered as a friendly country to Bangladesh from its very beginning, there would be further trade and investment opportunities from USA. When formulating strategies from firm's perspective, USA firms may consider expanding their operations in Bangladesh in above mentioned sectors. Such an identification of sectors in this study also support the market data was prepared previously for US investors. Moreover, strategic trade and investment policies might also be initiated from government level. US government may find Bangladesh as a potential location for furthering their investment opportunities while Bangladesh government should initiate more friendly investment opportunities to attract more USA investment.

Therefore, though this study explores the USA FDI potentiality in Bangladesh, such studies is not limited to only in one destination. Further studies can be initiated to explore more FDI opportunities for USA in similar other developing countries. Moreover, along with investment opportunities, trade nature and potentiality between Bangladesh and USA might also be explored in future studies. A secondary data, collected from previously established reports and studies might be considered limited for a study, however, this approach adopted in this study, would enhance the need of conducting an exploratory research. Above mentioned future studies, thus world be appropriate to make more in depth analysis of this issues.

\section{References}

Bryman, A. (2001). Social Research Methods. Oxford: Oxford University Press.

Creswell, J. W. (2003). Research design: Qualitative, quantitative and mixed method approaches (2nd ed.). California: Sage.

The Embassy of Bangladesh in Washington DC - US-Bangladesh Investment. Retrieved March 23, 2017, from http://www.bdembassyusa.org/index.php?page=us-bangladesh-investment

Bangladesh Bank, Survey report 2014.

Bangladesh Bank Survey report 2015

Bangladesh Bank, Foreign Direct Investment (FDI) in Bangladesh, Survey Report, 2016.

Bangladesh Power Development Board (2010), Power System Master Plan.

Bangladesh Investment Development Authority BIDA (various years), reports and documents. Retrieved from www.boi.gov.bd/

U. S Chamber of Commerce: International Affairs, (2013).THE UNITED STATES AND BANGLADESH: TOWARD THE FUTURE: Policy Recommendations to Strengthen the U.S.-Bangladesh Commercial Relationship"

Correspondent bdnews24.com, \%. (2016). Major US investors keen to invest in Bangladesh. Retrieved March 23, 2017, from http://bdnews24.com/business/2015/02/07/major-us-investors-keen-to-invest-in-bangladesh.

Indicators of Foreign Direct Investment Regulation - World Bank Group. (2016). Retrieved March 23, 2017, from http://iab.worldbank.org/

W. (2016). Data on Bangladesh, India, Pakistan and Sri Lanka- Investing Across Borders - World Bank Group. Retrieved March 23, 2017, from http://iab.worldbank.org/data/exploreeconomies/bangladesh

Islam. S. (2012, May 1). Bangladesh-US relations: Progress and prospects. Retrieved March 23, 2017, from $\mathrm{http}: / /$ print.thefinancialexpress-bd.com/old/more.php?news_id=128310\&date $=2012-05-01$

Report, S. B. (2015, May 24). Bangladesh invites US firms to invest in infrastructure. Retrieved March 23, 2017, from http://www.thedailystar.net/business/bangladesh-invites-us-firms-invest-infrastructure-85291.

MSU. (2016, March 10). Market Potential Index (MPI) - 2016. Retrieved March 23, 2017, from https://globaledge.msu.edu/mpi/data/2016

Bernicat (2016, October 27). US investment in Bangladesh on the rise. Retrieved March 23, 2017, from http://www.thedailystar.net/business/us-investment-bangladesh-the-rise-bernicat-1305529

Ahmed .N. (2016, 14 February). Chevron in Bangladesh Delivering Energy and Empowering the Community. Retrieved from http://www.daily-sun.com/printversion/details/114028/Chevron-in-Bangladesh-Delivering-Energy-and-Emp 
owering-the-Community

IMS Health Annual Report (10-K). Unleashing intelligence. - s2.q4cdn.com. (2014). Retrieved March 23, 2017, fromhttp://www.bing.com/cr?IG=96019491D2F74190A0B4941FBF10B52F\&CID=27D29E4782E06FFB3 71D940983D16EEF\&rd=1\&h=p0LRyf8qT8THt3Qi3WOYhD9ENJDsxEkWtWRjg4inPg\&v=1\&r=http\%3 a\%2f\%2fs 2.q4cdn.com\%2f521378675\%2ffiles\%2fdoc_financials\%2f2014\%2fIMS_2014_AnnualReport_F inal.pdf\&p=DevEx,5074.1

\section{Appendix}

FDI inflows, Sector-wise FDI inflows and FDI stocks From USA in Bangladesh

Table 1B: Data of Table 1A Restructured for Trend Values for FDI Inflow during 1996 - 2016

\begin{tabular}{llllll}
\hline Year & FDI (Y) & $\begin{array}{c}\text { Coded value, } \\
\text { X=Year-2006 }\end{array}$ & XY & $X^{2}$ & $\hat{Y}=\hat{\alpha}+\hat{\beta} X$ \\
\hline $\mathbf{1 9 9 6}$ & 14.39 & -10 & -143.9 & 100 & 11.99 \\
$\mathbf{1 9 9 7}$ & 67.64 & -9 & -608.76 & 81 & 22.38 \\
$\mathbf{1 9 9 8}$ & 232.9 & -8 & -1863.2 & 64 & 32.77 \\
$\mathbf{1 9 9 9}$ & 66.9 & -7 & -468.3 & 49 & 43.16 \\
$\mathbf{2 0 0 0}$ & 29.34 & -6 & -176.04 & 36 & 53.55 \\
$\mathbf{2 0 0 1}$ & 30.85 & -5 & -154.25 & 25 & 63.94 \\
$\mathbf{2 0 0 2}$ & 24.5 & -4 & -98 & 16 & 74.33 \\
$\mathbf{2 0 0 3}$ & 32.1 & -3 & -96.3 & 9 & 84.72 \\
$\mathbf{2 0 0 4}$ & 61.76 & -2 & -123.52 & 4 & 95.11 \\
$\mathbf{2 0 0 5}$ & 141.8 & -1 & -141.8 & 1 & 105.5 \\
$\mathbf{2 0 0 6}$ & 175.72 & 0 & 0 & 0 & 115.89 \\
$\mathbf{2 0 0 7}$ & 120.36 & 1 & 120.36 & 1 & 126.28 \\
$\mathbf{2 0 0 8}$ & 40.92 & 2 & 81.84 & 4 & 136.67 \\
$\mathbf{2 0 0 9}$ & 42.89 & 3 & 128.67 & 9 & 147.06 \\
$\mathbf{2 0 1 0}$ & 56.95 & 4 & 227.8 & 16 & 157.45 \\
$\mathbf{2 0 1 1}$ & 117.74 & 5 & 588.7 & 25 & 167.84 \\
$\mathbf{2 0 1 2}$ & 43.8 & 6 & 262.8 & 36 & 178.23 \\
$\mathbf{2 0 1 3}$ & 75.95 & 7 & 531.65 & 49 & 188.62 \\
$\mathbf{2 0 1 4}$ & 33.67 & 8 & 269.36 & 64 & 199.01 \\
$\mathbf{2 0 1 5}$ & 573.77 & 9 & 5163.93 & 81 & 209.4 \\
$\mathbf{2 0 1 6}$ & 449.74 & 10 & 4497.4 & 100 & 219.79 \\
\hline $\mathbf{5 0 4}:$ & 56 & 2016 & & & \\
\end{tabular}

Source: Bangladesh Bank, Survey Report, 2016.

Table: FDI Stock of USA, UK, South Korea \& Japan in Bangladesh from 2000- 2016

\begin{tabular}{lllll}
\hline FDI Stock & In Million US\$ & & & \\
\hline year & USA & UK & South korea & Japan \\
$\mathbf{2 0 0 0}$ & 356.55 & 506.78 & 183.28 & 320.54 \\
$\mathbf{2 0 0 1}$ & 284.6 & 757.14 & 160.3 & 294.6 \\
$\mathbf{2 0 0 2}$ & 307.85 & 816.5 & 175.06 & 259.94 \\
$\mathbf{2 0 0 3}$ & 324.28 & 842.25 & 186.52 & 272.93 \\
$\mathbf{2 0 0 4}$ & 458.35 & 934.41 & 192 & 214.93 \\
$\mathbf{2 0 0 5}$ & 484.36 & 1118.03 & 202.51 & 218.34 \\
$\mathbf{2 0 0 6}$ & 687.45 & 998.22 & 264.08 & 167.03 \\
$\mathbf{2 0 0 7}$ & 841.27 & 1121.07 & 209.83 & 154.05 \\
$\mathbf{2 0 0 8}$ & 827.52 & 1307.18 & 254.34 & 374.74 \\
$\mathbf{2 0 0 9}$ & 665.49 & 1345.72 & 285.42 & 409.8 \\
$\mathbf{2 0 1 0}$ & 705.16 & 1023.57 & 332.51 & 452.5 \\
$\mathbf{2 0 1 1}$ & 761.39 & 1056.23 & 382.44 & 456.08 \\
$\mathbf{2 0 1 2}$ & 696.66 & 780.42 & 436.5 & 230.68 \\
$\mathbf{2 0 1 3}$ & 551.49 & 1043.84 & 795.64 & 423.64 \\
\hline
\end{tabular}




\begin{tabular}{lllll}
\hline $\mathbf{2 0 1 4}$ & 624.98 & 1018.9 & 868.05 & 303.3 \\
$\mathbf{2 0 1 5}$ & 2811.94 & 1294.42 & 1019.93 & 297.59 \\
$\mathbf{2 0 1 6}$ & 3204.85 & 1526.37 & 1082.43 & 311.33 \\
\hline
\end{tabular}

Source: Bangladesh Bank, Survey Report, 2016.

FDI stock of USA in Different sectors of Bangladesh from 2014-2016

\begin{tabular}{llll}
\hline FDI Stock & in million US\$ & & 2014 \\
\hline Sectors & 2016 & 2015 & 33.04 \\
Textile and Wearing & 32.81 & 31.13 & 3.56 \\
Telecommunication & 6.78 & 4.98 & 177.2 \\
Banking & 176.67 & 181.98 & 289.25 \\
Gas \& Petroleum & 2653.06 & 2460.03 & 0.31 \\
Power & 1.46 & 18.82 & 1.28 \\
Food & 0.26 & 2.15 & \\
Trading & 7.22 & 1.3 & 3.06 \\
Insurance & & & 76.69 \\
Computer Software \& IT & 6.29 & & \\
Construction & & 2.93 & \\
Other Sector & 309.4 & 97.47 & \\
\hline
\end{tabular}

Source: Bangladesh Bank, survey report (2014-2016).

Compound growth rate of Sector wise FDI inflows from USA (in million US\$)

\begin{tabular}{lllllll}
\hline Sector & $\mathbf{2 0 1 1}$ & $\mathbf{2 0 1 2}$ & $\mathbf{2 0 1 3}$ & $\mathbf{2 0 1 4}$ & $\mathbf{2 0 1 5}$ & CGR (\%) \\
\hline Power & 58.4 & 67.31 & 69.82 & 45.48 & 247.76 & 44 \\
Gas \& Petroleum & 179.8 & 59.34 & 29.06 & 4.36 & 325.84 & 16 \\
Textiles \& Wearing & 272.04 & 307.48 & 421.63 & 390.92 & 442.92 & 13 \\
Chemicals \& Pharmaceuticals & 13.17 & 20.48 & 33.5 & 39.97 & 30.06 & 23 \\
Computer Software \& IT & 3.1 & 12.16 & 37 & 10.43 & 8.26 & 28 \\
Construction (c) & 0.45 & 2.9 & 6.53 & 7.94 & 4.91 & 82 \\
\hline
\end{tabular}

Source: Bangladesh Bank, Survey report, 2015.

\section{Copyrights}

Copyright for this article is retained by the author(s), with first publication rights granted to the journal.

This is an open-access article distributed under the terms and conditions of the Creative Commons Attribution license (http://creativecommons.org/licenses/by/4.0/). 